\title{
Key steps to smart specialization development of Russian regions
}

\author{
Yu.G. Myslyakova $\bowtie$, E.A. Shamova, N.P. Neklyudova \\ Institute of Economics of the Ural Branch of the Russian Academy of Sciences, Ekaterinburg, Russia; \\ mysliakova.ug@uiec.ru
}

\section{ABSTRACT}

Relevance. The development of modern mechanisms for state regulation of regional processes, including those related to investment support for certain industries (e.g. the Spatial Development Strategy in Russia), requires a research-informed choice of "priority" specializations. At the same time, such choice should meet the requirement of resilient economic development of these regions if the development of these specializations is supported on the national level. Research objective. The goal of this study is to assess the current structure of the Russian regions' economy. We aim to identify the regions that have a specialization and thus can ensure resilient development and transition to smart specialization. Data and methods. The study proposes a methodological approach to identify the region's smart specialization. The approach is based on the calculation of indicators that characterize the regions' industries according to Russia's national classifier of types of economic activity (OKVED2). Regions with pronounced industrial specialization are thus identified. The methodological approach has been tested by using statistical data for 84 regions. Results. 43 regions with industrial, export-oriented and extractive specialization were identified. We revealed nine regions that had sufficient prerequisites for the transition to smart specialization and 11 regions that need to strengthen their knowledge-intensive component. Conclusion. The resulting list of Russian regions that can act as pioneer territories for the introduction of structural changes into the practice of state regulation can be of interest to policy-makers.
\end{abstract}

\section{KEY WORDS}

region, regional economic stability, smart specialization, stages of formation, genetic approach

\section{ACKNOWLEDGEMENTS}

The research was conducted in execution of the state assignment of the Ministry of Science of the Russian Federation to the Institute of Economics of the Ural Branch of the Russian Academy of Sciences.

\section{FOR CITATION}

Myslyakova, Yu.G., Shamova, E.A., Neklyudova, N.P. (2021) Key steps to smart specialization development of Russian regions. R-economy, 7(2), 123-132. doi: 10.15826/recon.2021.7.2.011

\section{Основные этапы формирования SMART-специализации российских регионов}

\author{
Ю.Г. Мыслякова $₫$, Е.А. Шамова, Н.П. Неклюдова \\ Институт экономики УрО РАН, Екатеринбург, Россия; mysliakova.ug@uiec.ru
}

\section{АННОТАЦИЯ}

Актуальность. Развитие современных механизмов государственного регулирования региональных процессов, в том числе, касающихся вопросов инвестиционной поддержки определенных отраслей в рамках Стратегии пространственного развития, требует научно обоснованного выбора «приоритетных» специализаций регионов РФ. При этом их перечень должен отвечать требованию устойчивого экономического развития регионов в случае если данные специализации действительно получат государственную поддержку и начнут усиливаться. Целью настоящего исследования является оценка сложившейся структуры экономики регионов Российской Федерации, направленная на выявление регионов, имеющих специализацию, позволяющую обеспечить их региональное устойчивое развитие, а также имеющих предпосылки к переходу на смарт-специализацию. Данные и методы. Разработан методический подход к идентификации этапа формирования смарт-специализации региона, основанный на расчете показателей локализации отраслевых разделов по данным ОКВЭД2, обеспечивающего устойчивое развитие его экономики. Методика позволяет выявить регионы, имеющие ядро специализации, а также определить из их числа территории, обладающие наибольшей предрасположенностью к инновацион(c) Myslyakova, Yu.G., Shamova, E.A., Neklyudova, N.P., 2021

\section{КЛЮЧЕВЫЕ СЛОВА}

регион, региональная экономическая устойчивость, смарт-специализация, этапы формирования, генетический подход

\section{БЛАГОДАРНОСТИ}

Работа выполнена в рамках государственного задания Минобрнауки РФ Института экономики УрО РАН. 
ным трансформациям. Предложенный авторами методологический подход апробирован с использованием статистических данных по 84 регионам России. Результаты. В результате исследования были выявлено 43 субъекта Федерации с ядром специализации, имеющие отраслевую, экспортоориентированную и экстрактивную специализацию. Идентифицировано 9 регионов, имеющих полностью сформировавшиеся предпосылки к эволюционному переходу на смарт-специализацию экономики, а также 11 территорий, которым для эффективного перехода на смарт-специализацию необходимо усилить наукоемкую составляющую. Выводы. Полученный перечень субъектов Федерации, которые на сегодняшний день могут выступить пионерными территориями для внедрения в практику государственного регулирования структурных изменений в экономике с позиции инновационного и высокотехнологического развития может найти применение в практике работы государственных органов власти.

\section{ДЛЯ ЦИТИРОВАНИЯ}

Myslyakova, Yu.G., Shamova, E.A., Neklyudova, N.P. (2021) Key steps to smart specialization development of Russian regions. R-economy, 7(2), 123-132. doi: 10.15826/recon.2021.7.2.011

\section{Introduction}

National spatial and industrial-technological development should be well balanced to ensure the resilient economic growth of regions. Moreover, these way regions have specialization of their own and thus interregional competition is minimized, which means that the country's resources are used more efficiently.

The idea of introducing the principle of strategic coherence in Russian regional policies was included in the "Spatial Development Strategy of the Russian Federation for the Period until 2025", which was approved in 2019. This document indicates that to reduce regional disparities, it is necessary to identify potential centers of economic growth and their specializations. The prospective economic specialization of a Russian region consists of types of economic activity (industries) and is intended to provide this or that region with a competitive edge of its own.

The differentiation between "promising" and "unpromising" industries in regions, that is, between the industries that hold potential in a certain sphere and thus need to be supported by the government or not, in regional strategic management caused a heated discussion in the Russian academia (see Buchwald, Kolchugina, 2019; Leksin, 2019; Minakir, 2019). As Blanutsa (2020) shows, the differences between Russian regions are so significant that it is simply impossible to achieve the goal stated in the Strategy by 2025, and the differentiation between "promising" and "unpromising" industrial specializations cannot be seen as a panacea.

Ivanov and Buchwald (2019) also criticized this concept and showed that ensuring Russian regions have "promising" specialization of their own is a complicated task. Some regions have such specialization, others do not. Moreover, such specialization cannot always guarantee stable socio-economic development of a region.

Although the inclusion of a list of "promising specializations" in the Spatial Development Strategy can be considered can help coordinate the tasks of sectoral and spatial development of the Russian economy, the tools available today impede its effective implementation in the practice of public administration. It is necessary to conduct additional research to identify of Russian regions and their particulars.

The state structural policy should stimulate the formation of such type of specialization in regions for their stable development. In other words, a certain structure of regional economy should be built in order to help the region achieve its strategic goals despite various external challenges and threats. To reach this goal, it is necessary to develop not just priority sectors, but also increase the territory's own scientific and innovative potential and satisfy the needs of businesses, to take advantages of the existing opportunities and market trends, while avoiding duplication and fragmentation of efforts. Such type of specialization is known as smart specialization (Foray et al., 2012; Foray, 2014; Fagerberg, 2018; Morgan, 2017). Such specialization combines $\mathrm{R} \& \mathrm{D}$, technical, and innovative areas of activity and forms the transition from 'spatially blind' innovations to 'innovations on the ground' (McCann, Ortega-Argilés, 2015). It is based on the idea that the choice of priority activities of enterprises should be based on territorial potential (Capello \& Kroll, 2016). In this case, the sustainable development of regional economy is achieved not so much by institutionalizing government measures or supporting the expansion of small and large enterprises but through creating new knowledge that is adaptive 
to current economic practices and establishing cooperation between private and public sectors.

For stable regional development, it is necessary to model vectors of development of specific regions by taking into account their unique characteristics and trends. It is important to preserve this heritage in the regional economic system, adjusting its elements if necessary without violating the integrity of the region's unique socio-economic structure.

The above underpins the following hypothesis of this study: to ensure the stable growth of regional economy through industrial specialization, the stages of its formation must correspond to modern economic challenges and global trends in technological development.

The hypothesis determines the purpose of this study, which is to determine the main stages of regional transition to smart specialization, ensuring the resilient development of its economy in modern economic conditions.

To address this goal, we need to meet the following objectives: first, develop a methodological approach to identifying the stage of the region's specialization and, second, to formulate recommendations for ensuring regional transition to smart specialization. The practical significance of the research is that it describes a methodological tool that can be used by state decision-makers on the regional and national levels.

\section{Literature review}

The issues of sustainable regional development have been actively discussed for a long time in research literature. Even though there is a number of international studies on sustainable regional development, there is neither a generally accepted definition of the notion, nor a universal approach to how such development should be ensured.

The concept of sustainable development means that economic growth is associated with the minimization of negative environmental impacts and consequences for future generations (Glazyrina, Lavlinskii, 2017; Rahma et al., 2019). Later practitioners have criticized this approach on the grounds that it is difficult to implement, in particular regarding the achievement of the Millennium Goals (Larionova, 2020).

Recently, a resilience-orientated approach has been actively developed, where the regional resilient development of the economy is understood as its resistance to external shocks (resistance) as well as its ability to restore balance (recovery). Foster
(2007), one of the founders of this approach, interpreted resilience as a region's ability to forecast shocks, be alert to them, react, and recover after perturbation. Another prominent representative of this approach, Fingleton et al. (2012), proposed to combine the concept of sustainability with the concept of hysteresis in economics (the transition of the economy from one sustainable equilibrium to another) and regarded resilience as the ability of the economy to adapt its structure (corporate, industry, technological and institutional) to a new development pattern. The phenomenon of such a jump to a higher level of territorial performance, even if economic growth in its traditional meaning is impossible, is associated with a qualitative change in the object's structure as a result of the search for and activation of the so-called "growth frontiers" (Glasl, Lievegoed, 2000).

The hypothesis that specialization/diversification of the economy has an influence on its sustainability is quite popular in contemporary research. At the same time, the results of studies are often ambiguous due to significant differences of national economies and the diversity of connections between them.

Dissart (2003) explains that the diversification of a regional economy itself does not guarantee sustainability. The linkages between industries play a critical role in this. Lagravinese (2015) analyzed the development of Italian provinces and investigated the sensitivity of the regional economic sustainability indicator to its industrial structure. $\mathrm{He}$ concluded that specialization in non-manufacturing industries (in particular, services) positively affects the stability of regional economy, while the predominance of the manufacturing industry has a negative impact. In contrast, Mai et al. (2019) in their study of China show that the manufacturing industry plays a stabilizing role, while the most destabilizing influence is exerted by fast-growing industries such as the financial sector, construction, and real estate operations. Min J. et al. (2020) use American data to show how the structural composition of regional economies in the US affects the volatility of their economic growth. Malkina (2020) tested the hypothesis about the connection between the sustainability of regional economic development and the degree of industrial diversification. Although Malkina concluded that the sustainability of regional economy depends on diversification, but not on specialization, the actual material presented in the article shows a certain number of regions that 
have a stable state with a low diversified structure of the economy. Rocchetta and Mina (2019) argue that regions with technologically consistent and not just simply diversified knowledge bases are better prepared for unforeseen decline and show adaptive resilience. Moreover, regional economies are more adaptable if they introduce innovations in sectors with the highest growth potential.

The available research evidence shows that the specialization of different industries has a profound impact on sustainable development in different ways and its peculiarities determine a certain type of sustainable development. This fact once again shows the necessity to develop a methodological approach to identifying the stages of specialization development in a region's transition to smart specialization.

\section{Methodology and data}

The methodological approach to identifying the stages of regional smart specialization relies on the authors' understanding of sustainable development and the corresponding types of specializations (Fig. 1). Such understanding is based on the retrospective analysis of the emergence, growth, and decline of former industrial Russian and similar cases in other countries.

Each phase incorporates the previous ones and focuses on the development of the region's dominant industries. Therefore, the stages of regional transition to smart specialization should be based on the following principles:

- the principles of industrial specialization for closed steady development (i.e. development that occurs under the influence of dynamic environmental factors, leading the territory to depressive states (Kuzyk, Yakovets, 2005));

- the principles of export-oriented specialization, which ensures open steady development, but increases the region's dependence on the world market;

- the principles of specialization for stable development based on stimulating business investment flows into fixed assets of dominant or developing enterprises;

- the principles of high-tech or knowledge-intensive specialization to ensure the innovative sustainable development based on business-university interactions (professional and supra-professional competencies of employees are improved, the pool of patents is expanded and innovative solutions are commercialized (Bosch, Vonortas, 2019));

- the principles of smart specialization to ensure the technologically receptive resilient development. The approach is based on the new types of activities with innovative potential, created on the basis of historically established production determinants (Navarro, 2009; Fletcher, 2011; Benjamin et al., 2012); expanded opportunities for diversification of manufacturing production and technological areas that should be targeted by regional policies to promote innovation in these areas of specialization (McCann, Ortega-Argilés, 2015; Camagni, Capello, 2017).

The last stage is also characterized by the interaction of industrial enterprises, government, universities and local communities for creation

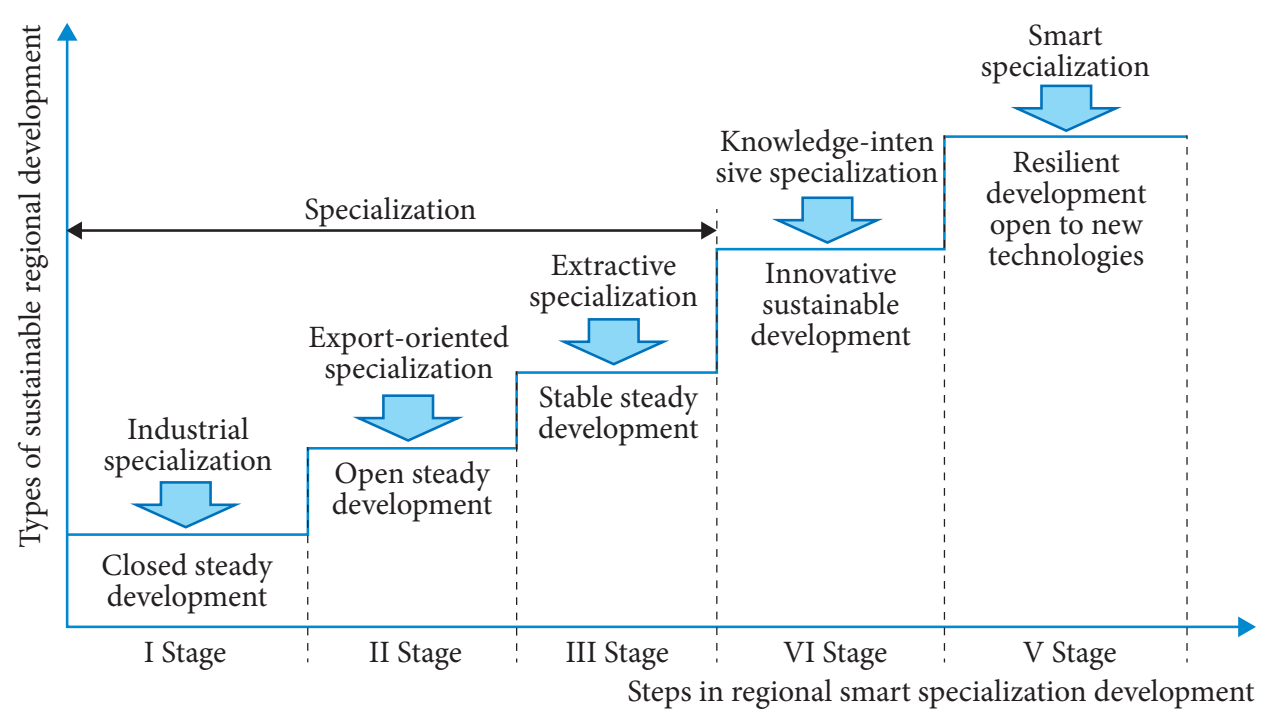

Figure 1. Evolutionary stages of regional smart specialization development. Source: compiled by the authors 
of modern and adaptive knowledge, primarily among young adults. At the same time, the formation of smart specialization occurs due to improved functionality of all participants: universities provide smart training; enterprises perform the functions of smart platforms to stimulate innovation; local communities act as carriers of smart knowledge, and regional authorities provide smart management that forms a new industrial policy. This functional interaction ensures the dynamism and flexibility of a regional economic system and makes the territory technologically receptive (Hudson, 2011).

The above-described approaches have determined our choice of methodological tools and methods for identifying the stage of formation of smart specialization by assessing the indicators of economic activities' localization in this or that region. We propose to focus on the transition to smart specialization which occurs if the region has a pronounced specialization. The industry at the core Therefore, the first methodological step is the study of the following four indicators of the relevant specialization in a region:

- gross regional product per capita (industrial specialization);

- goods produced, works performed and services rendered in this region (industrial specialization); zation);

- exported goods (export-oriented speciali-

- fixed capital expenditure (extractive specialization)

The localization indicator is calculated for each type of economic activity for each region according to the following formula (1):

$$
\operatorname{Loq}_{i j}=\frac{V_{i j} / \sum_{j=1}^{n} V_{i j}}{\sum_{j=1}^{n} V_{j} / \sum_{j=1}^{n} V_{i j}},
$$

where is the value of the indicator in industry $j$ in region $i$; $i$ is the numerical order of region $(i=1 \ldots m), m=84 ; j$ is the numerical order of economic activity $(j=1 \ldots m), m=19$.

The industrial specialization of a region is sustainably formed under the observance of $\operatorname{Loq}_{i j}>1.3$, which has the following economic meaning: share of the $i$-th type of economic activity in the $j$-th region is $30 \%$ or more than the share of the given industry nationwide. The 30\% excess is justified by the Pareto rule.
At the first stage, we evaluated the indicators "GRP per capita" and "Goods Shipped, Services Rendered" and thus identified the basic industrial specialization of the given region. The analysis of the indicators "Exported Goods" reveals its export-oriented specialization. The analysis of the indicator "Investment into Fixed Assets" reveals extractive specialization. If in the $i$-th type of economic activity of the $j$-th region all four indicators meet the condition $\operatorname{Loq}_{i j}>1.3$, then we characterize this type of economic activity as a sustainable industry specialization. Regions that have at least one type of economic activity with a stable industry specialization are included into a separate list. These regions for the studied period have a sectoral structural specialization, which allows the region to implement resilient development.

The second methodological step is to identify the regions with the core specialization those which have formed the conditions for the transition to smart specialization through knowledge-intensive specialization. To do this, we should assess the localization of regions by applying the following indicators:

- the share of professional education in the total value of education $(P)$ in the OKVED (all-Russian classifier of types of economic activity);

- the share of high-tech products in the total volume of goods shipped and services rendered.

We consider both of these indicators as prerequisites for further development of regions towards smart specialization. We analyzed the indicator "Share of Professional Education in the Total Value of Education" ("P" section in the OKVED) to identify the availability of higher education resources in this or that region. The analysis of the indicator 'Share of High-Tech Goods in the Total Volume of Goods Ships and Services Rendered' shows the region's disposition to modernization.

For clarity, we propose to consider all sectors of the OKVED2 as selected industries. These include agriculture, forestry and fishing (A); mining and quarrying $(B)$; manufacturing $(C)$; electricity, gas, steam and air conditioning supply $(D)$; water supply; sewerage, waste management and remediation activities $(E)$; construction $(F)$; wholesale and retail trade $(G)$; transportation and storage $(H)$, accommodation and food service activities $(I)$, information and communication $(J)$, financial and insurance activities $(K)$, real estate activities $(L)$, professional, scientific and technical activities $(M)$, administrative and support service activities $(N)$, public administration and defence; compul- 
sory social security $(O)$, education $(P)$, human health and social work activities $(Q)$, arts, entertainment and recreation $(R)$, other service activities $(S)$. The industries considered high-tech and research-intensive are shown in Table 1.

The evaluation period should cover at least three years, in our case, 2017-2019 (the period of OKVED2's validity). The base year for calculating the industrial specialization is 2019 , since the statistics for this period are the most relevant, and are devoid of significant distortions associated with the Covid-19 pandemic of 2020.

\section{Results}

Industrial specialization is not typical of all Russian regions. This follows from the analysis of the general level of their specialization. In general, we have identified 8 regions with a specialization in agriculture, forestry and fishing; 7 regions with a specialization in the extractive industry; 16 regions specializing in manufacturing, 2 regions with a specialization in trade and transportation, 13 regions with a specialization in health and social services, and 3 regions with a specialization in culture, sports, leisure and entertainment (Table 2).

The chosen regions have a stable industrial specialization, which means that they hold some promise in terms of smart specialization. We believe that the introduction of new approaches to managing regional development will be effective in those territories that have already created such conditions. Regional socio-economic systems can make an evolutionary transition to a new economic structure based on the principles of smart specialization, thus becoming the locomotives behind the introduction of high-tech production nationwide. experience in these territories, it can be transferred to other territories of the country.

As we noted above, the transition towards smart specialization is possible only in those regions that have the necessary resources for knowledge-intensive and high-tech economic development. Therefore, for the second step we are going to focus on these regions and assess their specialization (Table 3 ).

As Table 3 illustrates, only nine Russian regions have fully formed prerequisites for the transition to smart specialization. These are Voronezh, Moscow, Ryazan, Nizhny Novgorod, Sverdlovsk, Stavropol and Primorsky regions, republics of Bashkortostan and Chuvashia.

It should be noted that some regions included in Table 3, for an effective transition to smart specialization, need to strengthen the knowledge-intensive component or use the services of other territories. These regions include Bryansk, Kaluga, Oryol, Vladimir, Tver, Tula, Yaroslavl, Vologda, Novgorod, Kirov, and the Republic of Mari El.

Table 1

Types of Economic Activity Classified as High-Tech and Research-Intensive Industries \begin{tabular}{l|l} 
Code in OKVED2 & Economic activity
\end{tabular}

\begin{tabular}{|c|c|c|}
\hline \multicolumn{2}{|c|}{ Code in OKVED2 } & Economic activity \\
\hline \multicolumn{3}{|r|}{ High-tech and medium-tech industries } \\
\hline \multirow[t]{9}{*}{ Sector C } & 20 & Manufacture of chemicals and chemical products \\
\hline & 21 & Manufacture of basic pharmaceutical products and pharmaceutical preparations \\
\hline & 26 & Manufacture of computer, electronic and optical products \\
\hline & 27 & Manufacture of electrical equipment \\
\hline & 28 & Manufacture of other machinery and equipment \\
\hline & 29 & Manufacture of motor vehicles and motor vehicle parts \\
\hline & 30 & Manufacture of other transport equipment \\
\hline & 32.5 & Manufacture of medical instruments and supplies \\
\hline & 33 & Repair and installation of machinery and equipment \\
\hline \multicolumn{3}{|r|}{ Research-intensive industries } \\
\hline \multirow[t]{2}{*}{ Sector $\mathrm{H}$} & 50 & Water transport \\
\hline & 51 & Freight air transport and space transport \\
\hline \multirow[t]{3}{*}{ Sector J } & 61 & Telecommunications \\
\hline & 62 & Computer programming, consultancy and related activities \\
\hline & 63 & Information services \\
\hline \multirow[t]{2}{*}{ Sector M } & 71 & Architectural and engineering activities and related technical consultancy \\
\hline & 72 & Scientific research and development \\
\hline Sector P & 85.2 & Professional schools \\
\hline Sector Q & 86 & Health service \\
\hline
\end{tabular}

Source: Compiled by the authors 
Regions with a core specialization

\begin{tabular}{|c|c|c|c|c|c|c|c|c|}
\hline & \multicolumn{7}{|c|}{ Sectors of OKVED2* } & \multirow{2}{*}{$\begin{array}{c}\text { Number } \\
\text { of specializations }\end{array}$} \\
\hline & $A$ & $B$ & $C$ & G & $H$ & $Q$ & $R$ & \\
\hline Russian Federation & 8 & 7 & 16 & 2 & 2 & 13 & 3 & \\
\hline Central Federal District & 5 & $\mathbf{0}$ & 6 & 2 & $\mathbf{0}$ & 4 & $\mathbf{0}$ & \\
\hline Bryansk region & 1 & 0 & 0 & 0 & 0 & 0 & 0 & 1 \\
\hline Vladimir region & 0 & 0 & 1 & 0 & 0 & 0 & 0 & 1 \\
\hline Voronezh region & 1 & 0 & 0 & 0 & 0 & 0 & 0 & 1 \\
\hline Ivanovo region & 0 & 0 & 0 & 0 & 0 & 1 & 0 & 1 \\
\hline Kaluga region & 0 & 0 & 1 & 0 & 0 & 0 & 0 & 1 \\
\hline Kostroma region & 0 & 0 & 1 & 0 & 0 & 0 & 0 & 1 \\
\hline Kursk region & 1 & 0 & 0 & 0 & 0 & 0 & 0 & 1 \\
\hline Lipetsk region & 0 & 0 & 1 & 0 & 0 & 0 & 0 & 1 \\
\hline Moscow region & 0 & 0 & 0 & 1 & 0 & 1 & 0 & 2 \\
\hline Oryol region & 1 & 0 & 0 & 0 & 0 & 1 & 0 & 2 \\
\hline Ryazan region & 0 & 0 & 0 & 0 & 0 & 1 & 0 & 1 \\
\hline Tver region & 1 & 0 & 0 & 0 & 0 & 0 & 0 & 1 \\
\hline Tula region & 0 & 0 & 1 & 0 & 0 & 0 & 0 & 1 \\
\hline Yaroslavl region & 0 & 0 & 1 & 0 & 0 & 0 & 0 & 1 \\
\hline City of Moscow & 0 & 0 & 0 & 1 & 0 & 0 & 0 & 1 \\
\hline North West Federal District & 1 & 2 & 2 & $\mathbf{0}$ & $\mathbf{0}$ & $\mathbf{0}$ & $\mathbf{0}$ & \\
\hline Republic of Karelia & 1 & 0 & 0 & 0 & 0 & 0 & 0 & 1 \\
\hline Republic of Komi & 0 & 1 & 0 & 0 & 0 & 0 & 0 & 1 \\
\hline Arkhangelsk region & 0 & 1 & 0 & 0 & 0 & 0 & 0 & 1 \\
\hline Vologda region & 0 & 0 & 1 & 0 & 0 & 0 & 0 & 1 \\
\hline Novgorod region & 0 & 0 & 1 & 0 & 0 & 0 & 0 & 1 \\
\hline South Federal District & $\mathbf{0}$ & $\mathbf{0}$ & 1 & $\mathbf{0}$ & 1 & 2 & 1 & \\
\hline Republic of Adygea & 0 & 0 & 0 & 0 & 0 & 1 & 0 & 1 \\
\hline Krasnodar region & 0 & 0 & 0 & 0 & 1 & 1 & 1 & 3 \\
\hline Volgograd region & 0 & 0 & 1 & 0 & 0 & 0 & 0 & 1 \\
\hline North Caucasian Federal District & 0 & 0 & 0 & 0 & 0 & 3 & 1 & \\
\hline Kabardian-Balkar Republic & 0 & 0 & 0 & 0 & 0 & 1 & 0 & 1 \\
\hline Karachaev-Circassian Republic & 0 & 0 & 0 & 0 & 0 & 1 & 0 & 1 \\
\hline Stavropol region & 0 & 0 & 0 & 0 & 0 & 1 & 1 & 2 \\
\hline Volga Federal District & $\mathbf{0}$ & $\mathbf{0}$ & 4 & $\mathbf{0}$ & $\mathbf{0}$ & 3 & $\mathbf{0}$ & \\
\hline Republic of Bashkortostan & 0 & 0 & 1 & 0 & 0 & 0 & 0 & 1 \\
\hline Republic of Mari El & 0 & 0 & 1 & 0 & 0 & 1 & 0 & 2 \\
\hline Chuvash Republic & 0 & 0 & 0 & 0 & 0 & 1 & 0 & 1 \\
\hline Kirov region & 0 & 0 & 1 & 0 & 0 & 1 & 0 & 2 \\
\hline Nizhny Novgorod region & 0 & 0 & 1 & 0 & 0 & 0 & 0 & 1 \\
\hline Ural Federal District & $\mathbf{0}$ & 1 & 2 & $\mathbf{0}$ & $\mathbf{0}$ & $\mathbf{0}$ & $\mathbf{0}$ & \\
\hline Sverdlovsk region & 0 & 0 & 1 & 0 & 0 & 0 & 0 & 1 \\
\hline Khanty-Mansi Autonomous District & 0 & 1 & 0 & 0 & 0 & 0 & 0 & 1 \\
\hline Chelyabinsk region & 0 & 0 & 1 & 0 & 0 & 0 & 0 & 1 \\
\hline Siberian Federal District & $\mathbf{0}$ & 1 & 1 & $\mathbf{0}$ & $\mathbf{0}$ & $\mathbf{0}$ & $\mathbf{0}$ & \\
\hline Kemerovo region (Kuzbas) & 0 & 1 & 0 & 0 & 0 & 0 & 0 & 1 \\
\hline Omsk region & 0 & 0 & 1 & 0 & 0 & 0 & 0 & 1 \\
\hline Far East Federal District & 2 & 3 & $\mathbf{0}$ & $\mathbf{0}$ & 1 & 1 & 1 & \\
\hline Zabaykalsky region & 0 & 1 & 0 & 0 & 0 & 0 & 0 & 1 \\
\hline Kamchatka region & 1 & 0 & 0 & 0 & 0 & 0 & 1 & 2 \\
\hline Primorsky region & 1 & 0 & 0 & 0 & 0 & 0 & 0 & 1 \\
\hline Khabarovsk region & 0 & 0 & 0 & 0 & 1 & 0 & 0 & 1 \\
\hline Amur region & 0 & 0 & 0 & 0 & 0 & 1 & 0 & 1 \\
\hline Sakhalin region & 0 & 1 & 0 & 0 & 0 & 0 & 0 & 1 \\
\hline Chukotka Autonomous District & 0 & 1 & 0 & 0 & 0 & 0 & 0 & 1 \\
\hline
\end{tabular}

Chukotka Autonomous District

* Specialization: 0 - no evidence, $\operatorname{Loq}_{i j}<1.3 ; 1$ - identified, $\operatorname{Loq}_{i j}>1.3$

Source: the authors' calculations based on statistical data (Rosstat), indices: "Structure of Gross Regional Product (OKVED2)" https://www.fedstat.ru/indicator/59450; "Goods Shipped, Works Performed, Services Rendered (by Type of Economic Activity) since 2017" https://www.fedstat.ru/indicator/57711; "Fixed Capital Expenditure by Type of Economic Activity" https://www.fedstat. ru/indicator/59084; “Goods Exported since 2017” https://www.fedstat.ru/indicator/58575 (Accessed: May 6, 2021). 
Table 3 by going through three stages of formation (in-

Russian regions with a predisposition to smart specialization

\begin{tabular}{|c|c|c|}
\hline & \multicolumn{2}{|c|}{ Predisposition } \\
\hline & $\begin{array}{l}\text { research-inten- } \\
\text { sive industries* }\end{array}$ & $\begin{array}{l}\text { high-tech } \\
\text { industries* }\end{array}$ \\
\hline \multicolumn{3}{|c|}{ Central Federal District } \\
\hline Bryansk region & 0 & 1 \\
\hline Vladimir region & 0 & 1 \\
\hline Voronezh region & 1 & 1 \\
\hline Kaluga region & 0 & 1 \\
\hline Moscow region & 1 & 1 \\
\hline Oryol region & 0 & 1 \\
\hline Ryazan region & 1 & 1 \\
\hline Tver region & 0 & 1 \\
\hline Tula region & 0 & 1 \\
\hline Yaroslavl region & 0 & 1 \\
\hline \multicolumn{3}{|c|}{ North West Federal District } \\
\hline Vologda region & 0 & 1 \\
\hline Novgorod region & 0 & 1 \\
\hline \multicolumn{3}{|c|}{ North Caucasian Federal District } \\
\hline Stavropol region & 1 & 1 \\
\hline \multicolumn{3}{|c|}{ Volga Federal District } \\
\hline Republic of Bashkortostan & 1 & 1 \\
\hline Republic of Mari El & 0 & 1 \\
\hline Chuvash Republic & 1 & 1 \\
\hline Kirov region & 0 & 1 \\
\hline Nizhny Novgorod region & 1 & 1 \\
\hline \multicolumn{3}{|c|}{ Ural Federal District } \\
\hline Sverdlovsk region & 1 & 1 \\
\hline \multicolumn{3}{|c|}{ Far East Federal District } \\
\hline Primorsky region & 1 & 1 \\
\hline \multicolumn{3}{|c|}{$\begin{array}{l}\text { Source: the authors' calculations based on statistical } \\
\text { data (Rosstat), indices: "Structure of Gross Regional Product } \\
\text { (OKVED2)" https://www.fedstat.ru/indicator/59450; "Goods } \\
\text { Shipped, Works Performed, Services Rendered (by Type of } \\
\text { Economic Activity) since 2017" https://www.fedstat.ru/indi- } \\
\text { cator/57711; "Fixed Capital Expenditure by Type of Econom- } \\
\text { ic Activity" https://www.fedstat.ru/indicator/59084; "Goods } \\
\text { Exported since 2017" https://www.fedstat.ru/indicator/58575 } \\
\text { (Accessed: May 6, 2021). }\end{array}$} \\
\hline
\end{tabular}

The rest of the regions, which were not included in Table 3, currently do not have pronounced specialization in the high-tech sector.

\section{Conclusion}

The paper demonstrates that for the transition of a region to smart specialization, its economy must have a core specialization, which is achieved dustry-oriented, export-oriented and extractive). After production facilities are localized and thus form the core of regional industrial specialization, the region may start its transition to smart specialization.

We identified the following regions with pronounced specialization: 15 regions in the Central Federal District (none of these regions has a specialization in mining; 5 specialize in agriculture and 6 , in manufacturing); 5 regions in the North-Western Federal District (2 regions have specialization in the extractive and manufacturing industries, and one in agriculture and forestry); in the Southern Federal District, 3 were chosen ( 2 have a specialization in the recreational and leisure sector and one region in the manufacturing industry); in the North Caucasus Federal District, 3 regions have a specialization in the recreational and leisure sector; in the Volga Federal District, five regions specialize in the manufacturing industry and the recreational sector; in the Ural Federal District, there are three regions (2 specialize in manufacturing and one in the extractive industry); in the Siberian Federal District two regions specialize in the extractive and manufacturing industries; seven regions in the Far Eastern Federal District have a specialization (2 specialize in fishing; 3 , in mining; one, in transport and one, in recreation and tourism). These territories were further analyzed in the context of their predisposition to smart specialization.

We found that nine Russian regions are ready for the evolutionary transition to smart specialization. Among these regions, Sverdlovsk Region is of special interest. It is an industrial driver of the Ural Federal District. Its industrial experience can be of use to other industrial regions of the country.

The next step in this research would be to develop the typology of regions depending on the stages of transition the regions are in. The typology will result in a ranking of regions to be supported on the national level to stimulate the country's technological transformation and ensure its resilient development.

\section{References}

Benjamin, D.J., Cesarini, D., Chabris, C.F., Glaeser, E.L., Laibson, D.I., Guðnason, V., Harris, T.B., Launer, L.J., Purcell, S., Smith, A.V., Johannesson, M., Magnusson, P.K., Beauchamp, J.P., Christakis, N.A., Atwood, C.S., Hebert, B., Freese, J., Hauser, R.M., Hauser, T.S., Grankvist, A., ...\& Lichtenstein, P. (2012). The Promises and Pitfalls of Genoeconomics. Annual Review of Economics, 4, 627-662. doi: 10.1146/annurev-economics-080511-110939 
Blanutsa, V.I. (2020). Perspective economic specializations for the Russian regions in the Strategy of spatial development: convergence clubs. Economics. Information Technologies, 47 (2), 233-243. (In Russ.). doi: 10.18413/2687-0932-2020-47-2-233-243

Bosch, A., \& Vonortas, N. (2019). Smart Specialization as a Tool to Foster Innovation in Emerging Economies: Lessons from Brazil. Foresight and STI Governance, 13(1), 32-47. (In Russ). doi: $10.17323 / 2500-2597.2019 .1 .32 .47$

Buchwald, Y.M., \& Kolchugina A.V. (2019). Spatial development strategy and national security priorities of the Russian Federation. Ekonomika regiona = Economy of Region, 15(3), 631-643. (In Russ.). doi: 10.17059/2019-3-1

Camagni, R., \& Capello, R. (2017). Regional innovation patterns and the EU regional policy reform: towards smart innovation policies. In Seminal Studies in Regional and Urban Economics (pp. 313-343). Springer, Cham. doi: 10.1111/grow.12012

Capello, R., \& Kroll, H. (2016). From theory to practice in smart specialization strategy: emerging limits and possible future trajectories. European Planning Studies, 24(8), 1393-1406. doi: $\underline{10.1080 / 09654313.2016 .1156058}$

Dissart, J.C. (2003). Regional Economic Diversity and Regional Economic Stability: Research Results and Agenda. International Regional Science Review, 26(4), 423-446. doi: $\underline{10.1177 / 0160017603259083}$

Fagerberg, J. (2018). Mobilizing innovation for sustainability transitions: a comment on transformative innovation policy. Research Policy, 47(9), 1568-1576. doi: 10.1016/j.respol.2018.08.012

Fingleton, B., Garretsen, H., \& Martin, R. (2012). Recessionary shocks and regional employment: evidence on the resilience of UK regions. Journal of Regional Science, 52(1), 109-133. doi: 10.1111/j.1467-9787.2011.00755.x

Fletcher, J.M. (2011). The promise and pitfalls of combining genetic and economic research. Health Economics, 20(8), 889-892. doi: 10.1002/hec.1745

Foray, D. (2014). Smart Specialisation: Opportunities and Challenges for Regional Innovation Policies. Routledge, London. Retrieved from http://139.91.189.42/Financing/Files/ProPeFiles79/Ses$\underline{\text { sion1_Foray.pdf }}$

Foray, D., Goddard, J., Goenaga, X., Landabaso, M., McCann, P., Morgan, K., Nauwelaers, C., \& Ortega-Argilés, R. (2012). Guide to Research and Innovation Strategies for Smart Specialisations (RIS3). European Commission, Brussels. Retrieved from https://apo.org.au/node/90736

Foster, K.A. (2007). A Case Study Approach to Understanding Regional Resilience. Working Paper 2007-08. Institute of Urban and Regional Development, University of California, Berkeley. Retrieved from https://escholarship.org/uc/item/8tt02163

Glasl, F., \& Lievegoed, B. (2000). Dynamic development of the company As enterprise pioneers and the bureaucracy can be efficient. Kaluga: Spiritual knowledge, 264 p. (In Russ.).

Glazyrina, I.P., \& Lavlinskii, S.M. (2017). Economic and ecological models in Russia's mining sector. Regional Research of Russia, 7(2), 180-187. doi: 10.1134/S2079970517020034

Hudson, R. (2011). From knowledge-based economy to... knowledge-based economy? Reflections on changes in the economy and development policies in the North East of England. Regional Studies, 45(7), 997-1012. doi:10.1080/00343400802662633

Ivanov, O.B., \& Buchwald E.M. (2019). "Perspective economic specialization" as the innovation of the regional development policy. ETAP: Economic Theory, Analysis, and Practice, 6, 49-65. (In Russ.). doi: 10.24411/2071-6435-2019-10122

Kuzyk, B.N., \& Yakovets, Yu.V. (2005). Russia-2050: innovation breakthrough strategy. Moscow: Publishing house Economika. 618 p. (In Russ.).

Lagravinese, R. (2015). Economic crisis and rising gaps North-South: evidence from the Italian regions. Cambridge Journal of Regions, Economy and Society, 8(2), 331-342. doi: 10.1093/cjres/rsv006

Leksin, V.N. (2019). The roads that we do not choose (on the government "Strategy of spatial development of the Russian federation for the period up to 2025"). Russian Economic Journal, 3, 3-24. (In Russ.) doi: 10.33983/0130-9757-2019-3-3-24

Mai, X., Chan, R.C., \& Zhan, C. (2019). Which Sectors Really Matter for a Resilient Chinese Economy? A Structural Decomposition Analysis. Sustainability, 11(22), 6333. doi: 10.3390/su11226333 
Malkina, M.Y. (2020). Assessment of resilient development of the regional economies based on Mahalanobis distances. Terra Economicus, 18(3), 140-159. (In Russ.). doi: 10.18522/2073-66062020-18-3-140-159

McCann, P., \& Ortega-Argilés, R. (2015). Smart specialization, regional growth and applications to European Union cohesion policy. Regional studies, 49(8), 1291-1302. doi: $\underline{10.1080 / 00343404.2013 .799769}$

Min, J., Agrusa, J., Lema, J., \& Lee, H. (2020). The Tourism Sector and US Regional Macroeconomic Stability: A Network Approach. Sustainability, 12(18), 7543. doi: 10.3390/su12187543

Minakir, P.A. (2019). Russian economic space: Strategic impasses. Ekonomika regiona = Economy of Region, 15(4), 967. (In Russ.). doi: 10.17059/2019-4-1

Morgan, K. (2017). Nurturing novelty: regional innovation policy in the age of smart specialisation. Environment and Planning C: Politics and Space, 35, 569-583. doi: 10.1177/0263774x16645106

Navarro, A. (2009). Genoeconomics: Promises and Caveats for a New Field. Annals of the New York Academy of Sciences, 1167(1), 57-65. doi: 10.1111/j.1749-6632.2009.04732.x

Rahma, H., Fauzi, A., Juanda, B., \& Widjojanto, B. (2019). Development of a Composite Measure of Regional Sustainable Development in Indonesia. Sustainability, 11, 5861. doi: 10.3390/su11205861

Rocchetta, S., \& Mina, A. (2019). Technological coherence and the adaptive resilience of regional economies. Regional studies, 53(10), 1421-1434. doi: 10.1080/00343404.2019.1577552

Larionova, M. (2020). The Challenges of Attaining the Millennium Development Goals (MDGs). International Organisations Research Journal, 15(1), 155-176. doi: 10.17323/1996-7845-2020-01-07

\section{Information about the authors}

Yuliya G. Myslyakova - Candidate of Sciences (Economics), Senior Researcher, Institute of Economics of the Ural Branch of the Russian Academy of Sciences; Scopus Author ID: 57190430830; ORCID: 0000-0001-7635-3601; Researcher ID: B-6076-2018 (29, Moskovskaya Street, Yekaterinburg, 620014, Russian Federation); e-mail: mysliakova.ug@uiec.ru

Elena A. Shamova - Candidate of Sciences (Economics), Senior Researcher, Institute of Economics of the Ural Branch of the Russian Academy of Sciences; Scopus Author ID: 57191536744 ; ORCID: 0000-0002-9784-0289; Researcher ID: I-8330-2016 (29, Moskovskaya Street, Yekaterinburg, 620014, Russian Federation; e-mail: shamova.ea@uiec.ru.

Natalia P. Neklyudova - Candidate of Sciences (Economics), Senior Researcher, Institute of Economics of the Ural Branch of the Russian Academy of Sciences; Scopus Author ID: 57190430407; ORCID: 0000-0002-5026-1394; Researcher ID: E-5849-2014 (29, Moskovskaya Street, Yekaterinburg, 620014, Russian Federation); e-mail: neklyudova.np@uiec.ru

ARTICLE INFO: received March 11, 2021; accepted May 31, 2021

\section{Информация об авторах}

Мыслякова Юлия Геннадьевна - кандидат экономических наук, старший научный сотрудник, Институт экономики УрO PAH; Scopus Author ID: 57190430830; ORCID: 00000001-7635-3601; Researcher ID: B-6076-2018 (Россия, 620014, Екатеринбург, ул. Московская, 29); e-mail: mysliakova.ug@uiec.ru

Шамова Елена Алексеевна - кандидат экономических наук, старший научный сотрудник, Институт экономики УрО PAH; Scopus Author ID: 57191536744; ORCID: 0000-0002-9784-0289; Researcher ID: I-8330-2016 (Россия, 620014, Екатеринбург, ул. Московская, 29); e-mail: shamova.ea@uiec.ru

Неклюдова Наталья Павловна - кандидат экономических наук, старший научный сотрудник, Институт экономики УрO PAH; Scopus Author ID: 57190430407; ORCID: 00000002-5026-1394; Researcher ID: E-5849-2014 (Россия, 620014, Екатеринбург, ул. Московская, 29); e-mail: neklyudova.np@uiec.ru

ИНФОРМАЦИЯ О СТАТЬЕ: дата поступления 11 марта 2021 г.; дата принятия к печати 31 мая 2021 г. 